\title{
Differential Distribution of ecNOS and iNOS mRNA in Rat Heart after Endotoxin Administration
}

\author{
Toshiyuki Ishiwata, MD, Fang Guo, MD, \\ Zenya NaITo, MD, Goro Asano, MD, \\ and Ryutaro NisHigAKI, ${ }^{1} \mathrm{MD}$
}

\begin{abstract}
SUMMARY
To evaluate the relationship between cardiovascular injury and the pathological significance of endothelial constitutive nitric oxide synthase (ecNOS) and inducible nitric oxide synthase (iNOS) in endotoxic shock, Wistar rats were injected intraperitoneally with $10 \mathrm{mg} / \mathrm{kg}$ Escherichia coli endotoxin and the resulting cardiovascular changes observed using immunohistochemistry, immunoelectron microscopy, the reverse transcription polymerase chain reaction (RT-PCR) and in situ hybridization at 4, 6, 8 and $10 \mathrm{~h}$ after endotoxin administration. Immunohistochemical and electron microscopic observations showed that ecNOS was localized in the cytoplasmic vesicles and rough endoplasmic reticulum of the endothelium of coronary arteries and intermyocardial capillaries in both control and endotoxin-treated rats. iNOS was localized in the cytoplasmic vesicles and endoplasmic reticulum of vascular endothelial cells, vascular smooth muscle cells and cardiomyocytes after endotoxin administration. The RT-PCR study confirmed the expression of ecNOS and iNOS mRNA in the heart tissues of all animals including controls. In situ hybridization showed that ecNOS mRNA was expressed in the cytoplasm of vascular endothelial cells in control and endotoxin-treated rats. After endotoxin administration, iNOS mRNA was strongly expressed in vascular endothelial cells, vascular smooth muscle cells, cardiomyocytes and a small number of macrophages. Bacterial lipopoly-saccharide induces rapid release of nitric oxide in the microvasculature and cardiomyocytes resulting in the depression of cardiomyocyte contraction. These findings may describe the cardiac response after endotoxin treatment. (Jpn Heart J 1997; 38: 445-455)
\end{abstract}

Key words: Nitric oxide synthase (NOS), Endotoxin, Immunohistochemistry, In situ hybridization, Reverse transcription polymerase chain reaction (RTPCR)

7 THE mechanism of depression in myocardial contractility by soluble mediators remains unclear. Cardiac contractility may be reduced in endo-

\footnotetext{
From the Department of Pathology, and 'First Department of Internal Medicine, Nippon Medical School, Tokyo, Japan.

Address for correspondence: Toshiyuki Ishiwata, MD, Department of Pathology, Nippon Medical School, 11-5 Sendagi, Bunkyo-ku, Tokyo 113, Japan.

Reccived for publication September 9, 1996.

Accepted January 27, 1997.
} 
toxic shock and high concentrations of exogenous nitric oxide (NO) impair cardiac function. The formation of nitric oxide from $\mathrm{L}$-arginine in mammalian cells is catalyzed by the enzyme nitric oxide synthase (NOS). ${ }^{1)}$ The activity of this enzyme has been associated with a number of important physiological functions, including the maintenance of vascular tone, neuronal signaling and the host response to infection. ${ }^{2,3)}$ Endotoxins stimulate the release of endogenous mediators such as endothelium-derived relaxing factor (NO), cytokines and tumor necrosis factors from plasma precursors or cells. ${ }^{1)}$ An excess of NO after lipopolysaccharide (LPS) stimulation may act on the guanylate cyclase in endothelial cells to reduce their release of NO.) This may produce a less thromboresistant surface, allowing deposition and activation of platelets. Furthermore, prolonged release of NO results in diminished vascular and myocardial contractility and induces hypotension. ${ }^{5)}$ However, in shock syndrome, the biological roles of NO and NOS in the heart are not fully understood. The relationships between endothelial constitutive NOS (ecNOS) and cytokine inducible NOS (iNOS) and endotoxic shock remain unknown. To investigate the relationship between cardiovascular injury and NOS induction in shock syndrome, we examined rat hearts after endotoxin administration using immunohistochemistry and immuno-electron microscopy, including the reverse transcription polymerase chain reaction (RTPCR) and in situ hybridization.

\section{Materials and Methods}

All studies were approved by the Animal Experimental Commitee of Nippon Medical School. Thirty-six male Wistar rats (250-350 g) were injected intraperitoneally with $10 \mathrm{mg} / \mathrm{kg}$ Escherichia coli lipopolysaccharide (Difco, Detroit, MI, USA). Eight control male rats were given intraperitoneal injections of normal saline. The test animals showed signs of shock at $4 \mathrm{~h}$ after endotoxin administration.

Plasma nitrite measurement: Blood was collected in heparinized tubes and centrifuged at 15,000 rpm for 5 minutes in a microcentrifuge. The plasma was decanted into clean tubes and stored at $-20^{\circ} \mathrm{C}$. Prior to assay, the plasma was centrifuged $\left(7000 \mathrm{rpm}\right.$ for $15 \mathrm{~min}$ at $4^{\circ} \mathrm{C}$ ) with a centricon-10 (exclusion molecular weight, 10,000; Amicon, Danvers, MA, USA) and the filtrates used for the determination. For nitrite measurement, $50-\mu 1$ of the plasma were incubated with an equal volume of Griess reagent at room temperature for 20 minutes in a microplate. The absorbance at $550 \mathrm{~nm}$ was mcasured and nitrite concentration was determined using a curve calibrated from sodium nitrite standards.

Morphological observation: The animals, including control rats, were sacrificed at various time points $(4,6,8$ and $10 \mathrm{~h})$ after endotoxin administration 
and exsanguinated from their descending aorta.

The anterior wall of the heart was dissected out and cut into small pieces immediately after sacrifice. The heart sections were stained with hematoxylin and eosin and with Heidenhein-iron-hematoxylin for basic evaluation of myocardial structure. For ultrastructural observation, tissues were fixed in $2.5 \%$ glutaraldehyde in $0.1 \mathrm{M}$ cacodylate buffer solution ( $\mathrm{pH} 7.4$ ) and post-fixed in $1 \%$ osmium tetroxide in $0.1 \mathrm{M}$ cacodylate buffer, dehydrated in graded ethanols and embedded in epoxy resin. Semithin sections were cut and suitable tissue areas were selected for electron microscopic observation. Ultrathin sections were cut with a diamond knife on an Ivan Sorvall MT-5000 ultramicrotome. The sections were stained with uranyl acetate and lead citrate and examined with a Hitachi H-7000 electron microscope at an accelerating voltage of $75 \mathrm{kv}$.

Immunohistochemical observation: For immunohistochemical observation, 4\% paraformaldehyde (PFA)-fixed frozen sections were cut at a thickness of $5 \mu \mathrm{m}$ using a cryostat, placed on 3-aminopropyl-triethoxy-coated (silane) slides and stained by the indirect immunoperoxidase method. Endogenous peroxidase was inhibited by treatment with $0.3 \% \mathrm{H}_{2} \mathrm{O}_{2}$ in $100 \%$ methanol. Reaction with monoclonal mouse anti-ecNOS antibody (Transduction Laboratories, Lexington, KY, USA) and polyclonal rabbit anti-iNOS antibody (Affinity Bioreagents, Inc., Golden, CO, USA) was performed at a dilution of 1:400 with overnight incubation at $4^{\circ} \mathrm{C}$. After incubation with the primary antibody, the sections were treated with peroxidase-conjugated $\mathrm{F}\left(\mathrm{ab}^{\prime}\right)$ fragments of goat anti-rabbit IgG (Jackson Immunoresearch Laboratories, Inc., West Grove, PA, USA) at a 1:50 dilution for the iNOS antibody or with peroxidase-conjugated $F\left(a b^{\prime}\right)$ fragments of goat anti -mouse IgG (Medical and Biological Laboratories, Nagoya, Japan) at a 1:50 dilution for the ecNOS antibody. The sections were incubated with diaminobenzidine tetrahydrochloride as a substrate and then counterstained with hematoxylin.

Immunoelectron microscopic observation: For the ultrastructural observation of immunostaining, tissue sections were post-fixed in $1 \%$ osmium tetroxide in $0.1 \mathrm{M}$ cacodylate buffer after development of the peroxidase reaction. The sections were then dehydrated in a graded ethanol series and embedded in epoxy resin. Semithin sections were cut and suitable tissue areas were selected for electron microscopy. Ultrathin sections were cut with a diamond knife on an Ivan Sorvall MT-5000 ultramicrotome. The sections were observed with a Hitachi H7000 electron microscope at an accelerated voltage of $75 \mathrm{kV}$.

RT-PCR analysis: For RT-PGR analysis, total RNA was extracted from the heart tissues using Isogen (Nippon Gene, Tokyo, Japan). The first strands of cDNA were synthesized from $1 \mu \mathrm{g}$ total RNA with a 1st strand cDNA synthesis kit (Boehringer Mannheim GmbH, Mannheim, Germany). Oligonucleotide 
Table I. Oligonucleotide Primers

\begin{tabular}{lll}
\hline ecNOS & $\mathbf{F} ;$ & 5'-CCAGGGTGCGTGTGAAACTT-3' \\
& $\mathbf{R} ;$ & 5'-TCCGTCGTGGCTTCCAGTGT-3' \\
iNOS & $\mathbf{F} ;$ & 5'-CTCTGAAGAAATCTCTGTTC-3' \\
& $\mathbf{R} ;$ & 5'-TTGAGGTCTAGAGACTCTGG-3' \\
\multirow{2}{*}{ GAPDH } & F; & 5'-GCCAAGTATGATGACATCAA-3' \\
& R; & 5'-CGATATTCATTGTCATACCA-3' \\
\hline
\end{tabular}

Oligonucleotide primers were produced by a DNA synthesizer according to the rat ecNOS (partial sequence, directly submitted to Gen Bank by Bruce C. Kone U02534), iNOS and GAPDH sequences

primers were produced by a DNA synthesizer according to the rat ecNOS (partial sequence, directly submitted to Gen Bank by Bruce C. Kone, U02534), iNOS and GAPDH sequences (Table I). ${ }^{6}$ ) PCR was performed using a minor modification of a previously described method. ${ }^{7)}$ Each $50 \mu \mathrm{l}$ aliquot of the reaction mixture contained $5 \mu l$ of $10 \times$ PCR buffer (Boehringer Mannheim GmbH), $1 \mu l$ of each dNTP at $200 \mu \mathrm{M}, 2.5$ units Ampli Taq DNA polymerase (Boehringer Mannheim $\mathrm{GmbH}$ ), $250 \mathrm{ng}$ template cDNA and 100 pmol 5' and 3' primers. PCR was carried out in a thermal cycler (Perkin-Elmer Cetus, Norwalk, CT, USA) for 35 cycles, each consisting of $1 \mathrm{~min}$ at $95^{\circ} \mathrm{C}, 1 \mathrm{~min}$ at $55^{\circ} \mathrm{C}$ and $2 \mathrm{~min}$ at $72^{\circ} \mathrm{C}$. The PCR products were analyzed on $2 \%$ agarose gel. To exclude contamination with genomic DNA, each RNA sample was subjected to PGR without reverse transcriptase in an attempt to synthesize cDNA. No positive bands were detected in these samples. The band analysis was performed using an Epson scanner and the NIH software package Image 1.56. In this analysis, the width and density of each of the PCR-amplified products were corrected by those of GAPDH.

In situ hybridization: For in situ hybridization, the tissues were fixed in $4 \%$ PFA in phosphate-buffered saline (PBS) for $6 \mathrm{~h}$ at $4^{\circ} \mathrm{C}$. The tissues were then immersed in $20 \%(\mathrm{w} / \mathrm{v})$ sucrose in PBS containing $0.02 \%(\mathrm{w} / \mathrm{v})$ diethylpyrocarbonate (Sigma Chemical Co., St. Louis, MO, USA) at $4^{\circ} \mathrm{C}$ for about $16 \mathrm{~h}$ and frozen in OCT compound at $-80^{\circ} \mathrm{C}$. Frozen sections were cut with a cryostat at a thickness of $5 \mu \mathrm{m}$ and mounted on silane slides. According to the nucleotide sequences of rat ecNOS and iNOS cDNA, 50-mer oligonucleotides of ecNOS and iNOS were synthesized as probes. The oligonucleotide probe for iNOS encodes a sequence between the flavine adenine dinucleotide and the flavine mononucleotide binding sites. The sequence of the ecNOS oligonucleotide was 5'-AAGGGACAGAAGTGCGGGTATGGTCTGGAGCGCAGCGCAAACACACAGAA-3' and that of iNOS was 5'-GGATGTGAATGGAATGTTTGC-TTGGGACATGGAACGGCAC-ACAGGCTGGG-3'. The reverse sequences of these oligonucleotides were also synthesized for use as sense probes. The oligonucleotides were then labeled with digoxigenin (Dig)-dUTP by 
the $3^{\prime}$ tailing method using a DIG oligonucleotide tailing kit (Boehringer Mannheim $\mathrm{GmbH}$ ). In situ hybridization was performed as previously reported. ${ }^{7)}$ The sections were rehydrated with PBS and incubated with proteinase $\mathrm{K}(5 \mu \mathrm{g} /$ $\mathrm{ml}$, Signa Chemical Co.) in PBS for $15 \mathrm{~min}$ at $37^{\circ} \mathrm{C}$. The sections were then post-fixed in 4\% PFA/PBS for 5 min, quenched with glycine in PBS, and kept in $50 \%(\mathrm{v} / \mathrm{v})$ deionized formamide $/ 2 \times \mathrm{SSC}$ for $1 \mathrm{~h}$. One hundred microliters of hybridization buffer containing $100-300 \mathrm{ng} / \mathrm{m} l$ labeled probe was applicd to each section. Incubation was performed in a moist chamber for $18 \mathrm{~h}$ at $37^{\circ} \mathrm{C}$. The sections were then washed twice with $50 \%$ formamide $/ 2 \times \mathrm{SSC}$ for $15 \mathrm{~min}$ at room tempcrature and washed twice with $2 \times \mathrm{SSC}$ for $15 \mathrm{~min}$ at room temperature. For immunological detection, a nucleic acid detection kit (Boehringer Mannheim $\mathrm{GmbH}$ ) was employed. After stopping the reaction with TE buffer (10 mM Tris-HCl, $1 \mathrm{mM}$ EDTA, $\mathrm{pH} 8.0$ ), the sections were mounted in aqueous mounting medium (Daido Sangyo Co., Saitama, Japan).

\section{Results}

Plasma nitrite levels: The effects of endotoxin on NO production were investigated. The plasma $\left(\mathrm{NO}_{2}{ }^{-}\right)$concentrations at 4,6 and 8 hours after endotoxin administration were $2.91 \pm 3.20,5.07 \pm 3.46$ and $11.12 \pm 7.18 \mu \mathrm{M}$, respectively (Table II). In control rats and at 10 hours after endotoxin administration, plasma nitrite was not detectable.

Macroscopical and morphological observations: The animals became tachycardic and some died after $8 \mathrm{~h}$ of endotoxin administration. Light microscopically, irregular contraction of cardiomyocytes was observed in the early stage. After $8 \mathrm{~h}$ of endotoxin administration, occasional disintegration and vacuolization of the cardiomyocytes as well as lysis of myofibrils became prominent. Ultrastructurally, increased pinocytotic vesicles in endothelial cells associated with widened intercellular spaces, and vacuolization of endothelial and medial cells of the vasculature were observed. In cardiomyocytes, swelling of mito-

Table II. NO Production after Endotoxin Administration

\begin{tabular}{cc}
\hline $\begin{array}{c}\text { Time after endotoxin } \\
\text { administration [hours] }\end{array}$ & $\begin{array}{c}\text { Plasma nitrite }\left(\mathrm{NO}_{2}^{-}\right) \\
\text {concentration }[\mu \mathrm{M}]\end{array}$ \\
\hline Control & Not detectable \\
4 & $2.91 \pm 3.20$ \\
6 & $5.07 \pm 3.46$ \\
8 & $11.12 \pm 7.18$ \\
10 & Not detectable \\
\hline
\end{tabular}

Plasma nitrite values in rats after endotoxin administration. Nitrite values are higher at 4,6 and $8 \mathrm{~h}$ in treated rats than in non-treated rats. 


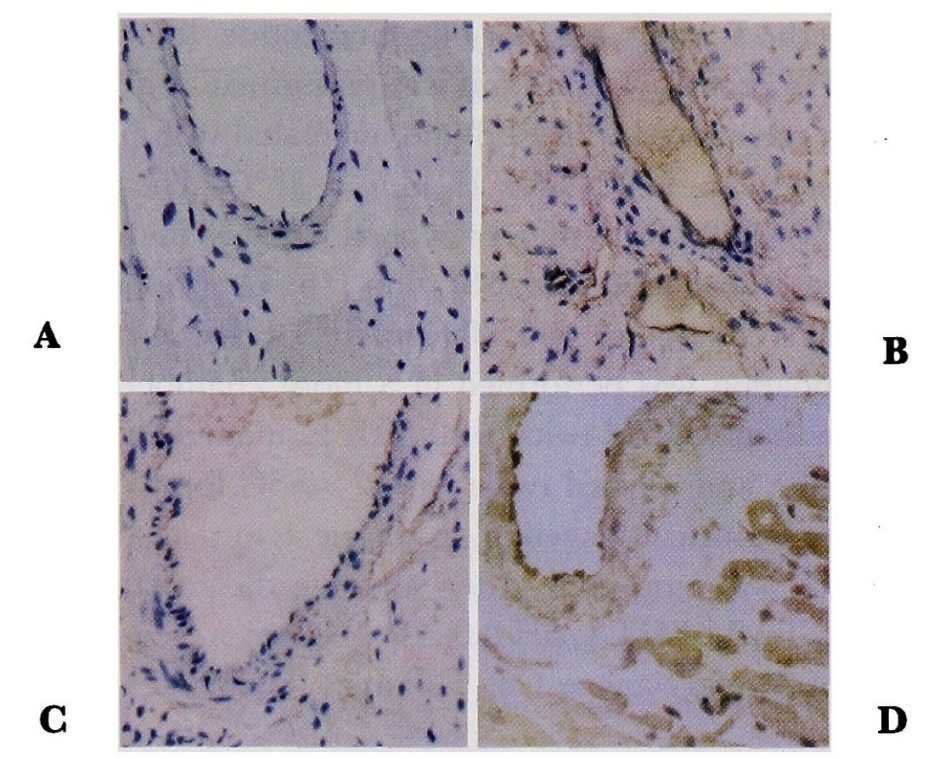

Figure 1. Immunohistochemical staining for ecNOS and iNOS.

A: No immunoprecipitate is observable on the sections treated without ecNOS antibody. Indirect method $\times 200$. B: In control rat hearts, ecNOS is localized in the vascular endothelial cells of coronary arteries and intermyocardial capillaries. Indirect method $\times 200$. C: In control rat hearts, iNOS immunoreactivity is faintly detectable in the vascular endothelial cells and vascular smooth muscle cells of coronary arteries. Indirect method $\times 200$. D: Eight hours after endotoxin administration, iNOS is localized in swollen vascular endothelial cells, vascular smooth muscle cells and degenerated cardiomyocytes. Indirect method $\times 200$.

A

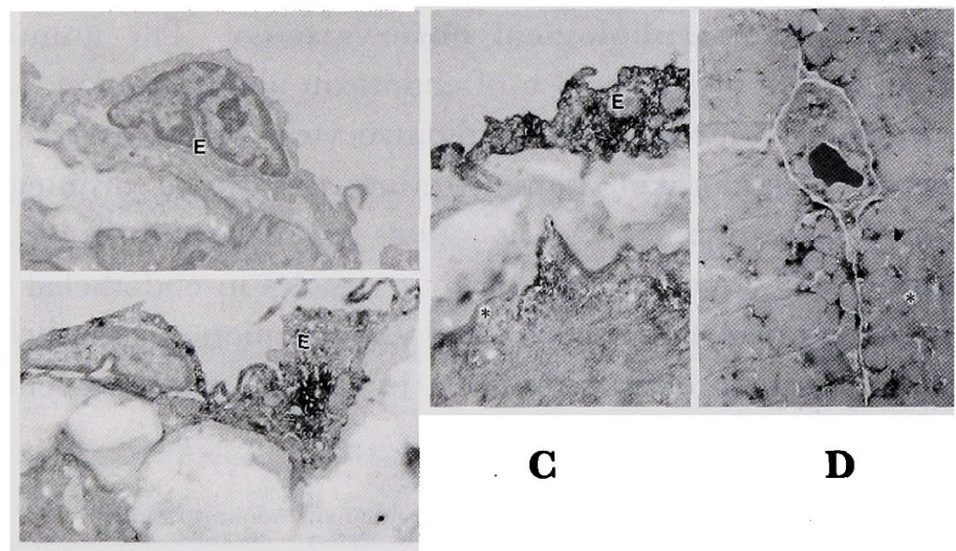

Figure 2. Electron microscopic immunohistochemical analysis.

A: Eight hours after endotoxin administration, no immunoprecipitate is observable in the sections treated without ecNOS antibody. Indirect method $\times 15,000$. B: Eight hours after endotoxin administration, increased ecNOS immunoreactivity is seen in the rough endoplasmic reticulum of the vascular endothelial cells of coronary arteries (E). Indirect method $\times 19,000$. C: Four hours after endotoxin administration, increased iNOS immunoreactivity is seen in the endoplasmic reticulum of the vascular endothelial cells (E) and vascular smooth muscle cells (asterix). Indirect method $\times 20,000$. D: Eight hours after endotoxin administration, increased iNOS immunoreactivity is seen in the endoplasmic reticulum of cardiomyocytes. Indirect method $\times 72,000$. 


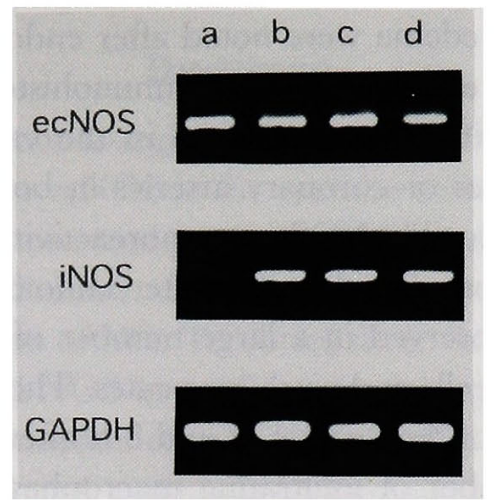

Figure 3. RT-PCR analysis of ecNOS and iNOS mRNA.

In all groups, PCR amplification products are detected at $264 \mathrm{bp}$ for ecNOS mRNA, at 352 bp for iNOS mRNA, a. control, b. $4 \mathrm{~h}$, c. $8 \mathrm{~h}, \mathrm{~d}$. $10 \mathrm{~h}$ after endotoxin administration.

A
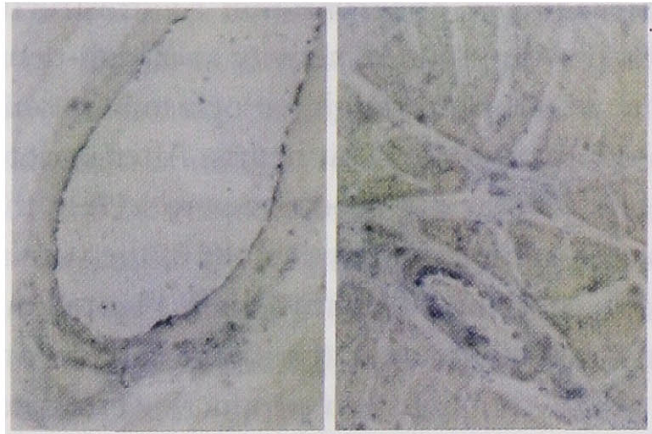

\section{C}

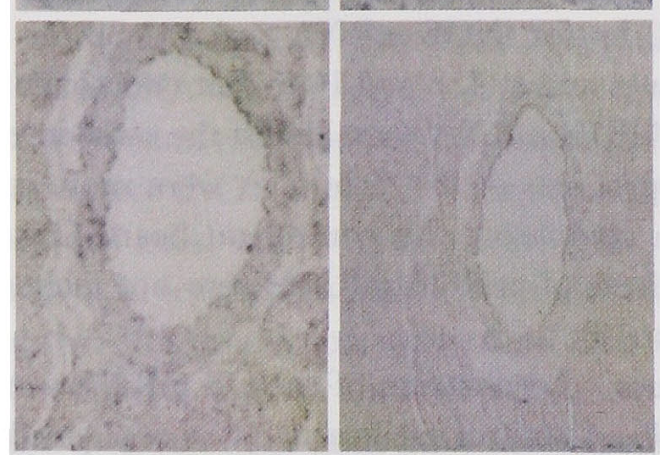

B

D

Figure 4. In situ hybridization with sense and anti-sense probes for ecNOS and iNOS.

A: In control rat heart, ecNOS mRNA is expressed in vascular endothelial cells. antisense $\times 200$. B: Four hours after endotoxin administration, ecNOS mRNA expression is detectable in swollen vascular endothelial cells. anti-sense $\times 200$. C: Six hours after endotoxin administration, iNOS mRNA expression is detectable in vascular endothelial cells, vascular smooth muscle cells and cardiomyocytes. anti-sense $\times 200$. D: Six hours after endotoxin administration, no positive signals could be found in vascular endothelial cells, vascular smooth muscle cells or cardiomyocytes with the iNOS sense probe. sense $\times 200$. 
chondria and interstitial edema were noted after endotoxin administration.

Immunohistochemical observations: Immunohistochemically, the immunoreactive products of ecNOS were localized in the vascular endothelial cells of intermyocardial capillaries or coronary arteries in both control and endotoxintreated heart tissues. Inducible NOS immunoreactivity was occasionally present in control vascular smooth muscle cells. After endotoxin administration, iNOS immunoreactivity was observed in a large number of vascular endothelial cells, vascular smooth muscle cells and cardiomyocytes. The immunoreactive products were clearly observable in the heart 4,6 and $8 \mathrm{~h}$ after endotoxin administration (Figure 1). A small number of infiltrating macrophages were also stained with iNOS antibody. No immunohistochemical staining was detected when tissue sections were treated either in the absence of primary antibody or in the presence of normal mouse or rabbit serum instead of ecNOS or iNOS primary antibody, respectively.

Immunoelectron microscopic observations: Ultrastructurally, ecNOS-positive endothelial cells showed immunoreactivity as a high-density immunoprecipitate in the cytoplasmic vesicles and rough endoplasmic reticulum of the endothelium in control and endotoxin-treated rat hearts. After endotoxin administration, increased amounts of iNOS reaction products were seen in the cytoplasmic membrane system, such as the endoplasmic reticulum of the vascular endothelial cells, vascular smooth muscle cells and cardiomyocytes (Figure 2). No immunoprecipitate was observed on the sections treated without ecNOS or iNOS antibody.

RT-PCR analysis: PCR amplification products were detected at 264 bp for ecNOS mRNA, 352 bp for iNOS mRNA and 202 bp for GAPDH mRNA in control rat heart tissues and at 4,8 and $10 \mathrm{~h}$ after endotoxin administration. RTPCR products of GAPDH mRNA were almost the same in each group, however the PCR-amplified products of iNOS mRNA were more increased after endotoxin administration compared with control rat heart. On the other hand, the PCR-amplified products of ecNOS mRNA were not increased after endotoxin administration (Figure 3).

In situ hybridization: Localization of ecNOS mRNA was evident in the vascular endothelial cells of control rat hearts on in situ hybridization. After endotoxin administration, ecNOS mRNA was found in the cytoplasm of swollen vascular endothelial cells. On the other hand, iNOS mRNA was faintly detectable in vascular endothelial cells, smooth muscle cells and infiltrating macrophages in control rats. After endotoxin administration, iNOS mRNA was localized in the cytoplasm of vascular endothelial cells, vascular smooth muscle cells and cardiomyocytes (Figure 4). 


\section{Discussion}

NO is synthesized from L-arginine by ecNOS, iNOS and neuronal NOS (nNOS). NO synthesized by ecNOS in the vascular endothelium plays a vital role in the control of vascular tone and prevention of thrombus formation. ${ }^{4)}$ On the other hand, iNOS is synthesized after injury or shear stress and catalyzes the production of large amounts of NO. To obtain more detailed information on the biological roles of NO and NOS in cardio- vascular injury resulting from septic shock, we examined the induction of ecNOS and iNOS in hearts after endotoxin administration. In control and endotoxin-treated rat heart, ecNOS and iNOS mRNA were detectable by RT-PGR. In previous studies, ecNOS has been observed in endothelial cells, and detected immunohistochemically in control hearts, while ecNOS mRNA has been detected in LPS-treated rat heart tissues. ${ }^{9,10)}$ In the present study, ecNOS and its mRNA were localized only in the endothelial cells of control and endotoxin-treated heart on examination using immunohistochemistry, immunoelectron microscopy and ISH. The number of ecNOS mRNA-positive cells and the amounts of ecNOS RT-PCR products did not increase after endotoxin administration. On the other hand, previous studies have found that iNOS mRNA could not be detected by northern blot analysis in control rat heart, ${ }^{11)}$ nor could iNOS be found in vascular endothelial cells or vascular smooth muscle cells. $\left.{ }^{12-14}\right)$ RT-PCR may detect the small amounts of iNOS mRNA synthesized by endothelial cells, smooth muscle cells and macrophages in control rat heart. After endotoxin administration, the intensity of the iNOS mRNA band was significantly increased. In a previous study using northern blot analysis, iNOS mRNA was the highest six hours after endotoxin administration. ${ }^{11)}$ After LPS treatment, myocytes, macrophages and smooth muscle cells have been shown to produce iNOS in vitro. ${ }^{15,16)}$ In our examination, iNOS was synthesized by myocardial cells, vascular endothelial cells, smooth muscle cells and macrophages in vivo. In sepsis, high plasma levels of $\mathrm{NO}^{2-}$ and $\mathrm{NO}^{3-}$ occur ${ }^{17-}$ ${ }^{19)}$ as a result of excessive NO production induced by iNOS, and this may contribute to the loss of peripheral vascular tone, depression of myocardial contractility and hypotension observed after endotoxin administration. Under specific inflammatory conditions, the generation of $\mathrm{NO}$ in vascular tissue switches from ecNOS in the endothelium to iNOS in vascular smooth muscle cells. Synergistic activation of NOS gene expression in vascular smooth muscle cells by interleukin $1 \beta$ and TNF may also contribute to hypotension in sepsis. ${ }^{17,18)}$ NOS may be present at a site where it can rapidly produce NO for release into the blood or alternatively toward vascular smooth muscle in many vascular beds. ${ }^{20,21)}$ Endotoxin-induced hypotension may be partially mediated by NO generated by iNOS in macrophages as well as in vascular endothelial cells, vascular smooth muscle 
cells and cardiomyocytes. The overproduction of NO by iNOS also plays a major role in hyperdynamic endotoxemia ${ }^{22)}$ The myocardium has the capacity to express iNOS and the presence of iNOS in cardiomyocytes may be an important regulator of contractile function in the heart. ${ }^{23-26)}$ Induction of NO synthase in the heart may explain the specific cardiac dysfunction of endotoxic shock. No synthase induction contributes to the pathogenesis of septic shock, and the inhibition of NO synthase may be useful for the treatment of septic shock. ${ }^{11)}$ Tsujino et al. reported that the sustained depression of myocardial contractility induced by cytokines may be partly mediated by local NO production, generated by enhanced iNOS activity in cardiomyocytes and non-myocytes such as vascular endothelial cells. ${ }^{27)}$ The role of NO overexpression in endotoxic shock is not clear at this point. However the regulation of iNOS synthesis by vascular endothelial cells, vascular smooth muscle cells, cardiomyocytes and macrophages may be one way to control endotoxin shock. ${ }^{25}$

Increased nitric oxide produced by non-cardiomyocytes including microvascular endothelial and smooth muscle cells and cardiomyocytes may contribute to the contractile dysfunction of heart after endotoxin treatment.

\section{ACKNOWLEDGMENTS}

The authors wish to thank Ms. Kiyoko Kawahara, Ms. Keiko Nishigai and Mr. Takenori Fujii for their skillful technical assistance.

\section{REFERENCES}

1. Moncada S, Higgs A. The L-arginine-nitric oxide pathway. New Engl J Med 1993; 329: 2002-12.

2. Preiser JC, Zhang $\mathbf{H}$, Wachel D, Boeynaems JM, Buurman W, Vincent JL. Is endotoxin-induced hypotension related to nitric oxide formation. Eur Surg Res 1994; 26: 10-8.

3. Gardiner M, Compton M, Bennet T, Palmer RM], Moncada S. Control of regional blood flow by endothelium-derived nitric oxide. Hypertension 1990; 15:486 92.

4. Curzen NP, Griffiths MJ, Evans TW. Role of the endothelium in modulating the vascular response to sepsis. Clin Sci 1994; 86: 359-74.

5. Kilbourn RG, Griffth OW. Overproduction of nitric oxide in cytokine-mediated and septic shock. J Nat Gancer Inst 1992; 84: 827-31.

6. Nunokawa $Y$, Ishida N, Tanaka S. Cloning of inducible nitric oxide synthase in rat vascular smooth muscle cells. Biochem Res Commn 1993; 191: 89-94.

7. Shiraishi A, Ishiwata T, Shoji T, Asano G. Expression of basic fibroblast growth factor, FGF-receptor and vascular endothelial growth factor in adenomas and carcinomas of human colon. Acta Histochem Cytochem 1995; 28: 21-9.

8. Fukui M, Qiao Y, Guo F and Asano G. Cell damage and liberation of nitric oxide synthase in rat heart induced by endotoxin administration. J. Nippon Med. Sch., 1995; 62: 469-81.

9. Ursell PC, Mayes M. Anatomic distribution of nitric oxide synthase in the heart. Int J Cardiol 1995; 50: 217-23.

10. Hom GJ, Grant SK, Wolfe G, Bach TJ, MacIntyre DE, Hutchinson NI. Lipopolysaccharide-induced hypotension and vascular hyporeactivity in the rat: tissue analysis of nitric oxide synthase mRNA and protein expression in the presence and absence of dexamethasone, NG-monomethyl-L-arginine or 
indomethacin. J Pharmacol Exp Ther 1995; 272: 452 9.

11. Luss H, Watkins SC, Freeswick PD, et al. Characterization of inducible nitric oxide synthase expression in endotoxemic rat cardiac myocytes in viwo and following cytokine exposure in vitro. $\mathrm{J}$ Mol Cell Cardiol 1995; 27: 2015-29.

12. Sirsjö A, Söderkvist $P$, Sundqvist $T$, et al. Different induction mechanisms of $m R N A$ for inducible nitric oxide synthase in rat smooth muscle cells in culture and in aortic strips. FEBS Lett 1994; 338: $191-6$.

13. Mollace V, Salvemini D, Anggard E, Vane J. Nitric oxide from vascular smooth muscle cells: regulation of platelet reactivity and smooth muscle cell guanylate cyclase. Br J Pharmacol 1991; 104: 633-8.

14. Bernhardt J, Tschudi MR, Dohi Y, et al. Release of nitric oxide from human vascular smooth muscle cells. Biochem Biophys Res Commn 1991; 180: 907-12.

15. Hattori $\mathrm{Y}$, So S, Hattori S, Kasai K, Shimoda S. Vesnarinone inhibits induction of nitric oxide synthase in J774 macrophages and rat cardiac myocytes in culture. Cardiovasc Res 1995; 30: 187-9.

16. Buttery LDK, Evans TJ, Springall DR, Carpenter A, Cohen J, Polak JM. Immunochemical localization of inducible nitric oxide synthase in endotoxin-treated rats. Lab Invest 1994; 71: 755-64.

17. MacNaul KL, Hutchinson NI. Differential expression of iNOS and cNOS mRNA in human vascular smooth muscle cells and endothelial cells under normal and inflammatory conditions. Biochem Biophys Res Commun 1993; 196: 1330-4.

18. Beasley $D$, Eldridge $M$. Interleukin- $1 \beta$ and tumor necrosis factor- $\alpha$ synergistically induce NO synthase in rat vascular smooth muscle cells. Am J Physiol 1994; 266: R1197-203.

19. Evans T, Carpenter A, Kinderman H, Cohen J. Evidence of increased nitric oxide production in patients with the sepsis syndrome. Circul Shock 1993; 41:77-81.

20. Pollock JS, Nakane M, Buttery DK, et al. Characterization and localization of endothelial nitric oxide synthase using specific monoclonal antibodies. Am J Physiol 1993; 265: C1379-87.

21. Loesch A, Belai A, Burnstock G. Ultrastructural localization of NADPH-diaphorase and colocalization of nitric oxide synthase in endothclial cells of the rabbit aorta. Cell Tissue Res 1993; 274: 539-45.

22. Meyer J, Lentz CW, Stothert JG, Traber LD, Herndon DN, Traber DL. Effcets of nitric oxide synthesis inhibition in hyperdynamic endotoxemia. Crit Care Med 1994; 22: 306-12.

23. Shindo $T$, Ikeda $U$, Ohkawa $F$, et al. Nitric oxide synthesis in rat cardiac myocytes and fibroblasts. Life Sci 1994; 55: 1101-8.

24. Petros A, Bennett D, Vallance P. Effect of nitric oxide synthase inhibitors on hypotension in patients with septic shock. Lancet 1991; 338: 1557-8.

25. Brady AJB, Poole-Wilson PA, Harding SE, Warren JB. Nitric oxide production within cardiac myocytes reduces their contractility in endotoxemia. Am J Physiol 1992; 263: H1963-6.

26. De Belder AJ, Radomski MW, Why HJF, et al. Nitric oxide synthase activities in human myocardium. Lancet 1993; 341: 84-5.

27. Tsujino $M$, Hirata $Y$, Imai $T$, et al. Induction of nitric oxide synthase gene by interleukin-1 $\beta$ in cultured rat cardiocytes. Circulation 1994; 90: 375-83. 